\title{
EX PARTE MAITLAND
}

\section{J. E. COTE*}

It is well known that Maitland long maintained that, despite appearances, law and equity never conflicted, but rather worked in harmony. Maitland reached the conclusion that, though the Judicature Acts provided that equity should prevail over law in cases of conflict, little substantive change was intended by that enactment. Indeed, the courts, since 1875, have reached the same conclusion; and have held that this statutory provision is of no substantive effect. The results of the Judicature Acts in this respect were purely procedural, as a recent article in this journal indicates. ${ }^{1}$

However, a little over fifty years ago, Hohfeld ·attacked Maitland's doctrine as being illogical; and stated that, as a matter of jurisprudential analysis, law and equity must be seen to conflict at some times, although not at others. This criticism seems to have gained considerable acceptance, especially in the United States; and apparently no one has undertaken a logical or jurisprudential defence of Maitland's view. Must Hohfeld's criticism now be accepted? Was Maitland wrong? Are the courts wrong today? These questions can be answered by first examining the relation of law and equity before the statutory reforms of the Nineteenth Century intervened, and then considering the effect of those statutes upon that relation.

\section{Before the Nineteenth Century Statutes}

This history of the emergence of English courts of equity has been so often and so well recounted ${ }^{2}$ that we may rest content with the briefest summary here. Long ago, at a time in English constitutional history when legal rules and courts of law were already established, the growing rigidity and formality of legal rules led to the practice of persons aggrieved addressing petitions to the King's Chancellor, asking him to grant relief from the harsh operation of the law. In time, this function of the Chancellor as a dispenser of individual justice became regularly established. A separate court of Chancery grew up around his office, and the rules as to when he would intervene hardened into precedents almost as fixed as those of the law. The rules produced by the Chancellor were extensive, and in certain areas formed quite as coherent and close-knit a system as did the legal rules. Yet, they applied to situations which the law also covered with its rules, and the Chancellor's dispositions were usually by no means the same as those of the courts of law. The rules of equity were plainly a regular part of the English legal system.

If those rules are to be discussed conveniently and accurately, some use must be made of the very notions which Hohfeld himself employad

- B.A. (Hons.) (McGill), LL.B. (Alta.). I should like to thank Mr. J. D. Dav.... of St. Catharine's College. Oxford, who has read this article in proof form and made a number of suggestions. He is not of course responsible for any of the manifest or latent errors contained herein.

1 Steer, The Present Status of Maitland's Equity (1963), 3 Alta. L. Rev. 5. See also Holdsworth. Equity (1935), 51 L.Q.R. 1942; Evershed, Reflections on the Fusion of Law and Equity (1954), 70 L.Q.R. 326.

21 Holdsworth, History of English Law Ch. 5 (6th ed. 1938); Maitland, Equity 1-14 (2d ed. 1949); Steer, ante, $n$. 1, at 5-7 
to analyze the problem. ${ }^{3}$ What are commonly called "rights" may actually be any one of four things. Firstly, the word "right" may be used strictly where one refers to a claim right, which one man has when another is under a duty to him to do or not to do some particular thing. For example, if $A$ is under a duty to pay $B$ a sum of money, $B$ has a claim right to be paid the money. Secondly, when we say "right" we may mean a power to cause legal effects. Thus, a man who owns a chattel has the power to cause title in the chattel to pass by a contract of sale. This is quite independent of any claim right to sell, for he might be under a contract with a third party not to sell, and so have no claim right to sell, but only a power to pass title. Thirdly, "right" may actually mean a liberty, which is the absence of duty. A person does not really have a claim right to walk down a public street, for no one is under a duty to assist in this act. But, conversely, no one has a right that this person not walk down the street (or, for that matter, that he walk); he is quite free to walk or not walk as he pleases, no claim rights or duties with respect to the matter existing at all. Finally, a "right" may be another kind of freedom, an immunity from others' powers. One does not really have a claim right that no one else take away title to one's goods; rather, they have no power to do so, and one has an immunity with respect to these goods. Therefore, whenever we wish to speak of "rights," we must consider whether we mean claim rights, powers, liberties, or immunities.

In the light of these terms then, what did the court of Chancery do? In time, it developed a considerable variety of different kinds of relief; but its major functions can be summed up quite simply under three headsthree different kinds of relief which plaintiffs sought in equity because they could not obtain them at law:

(a) The plaintiff in equity might be able to have the court of Chancery impose a new duty on the other party to do or not to do something, especially a duty not to enforce some legal claim right or power. For example, equity might issue a common injunction forbidding the other party from suing on a legal claim in the courts of law.

(b) The plaintiff in equity might secure an order imposing a new duty on the other party to hold some property or other benefit on behalf of the plaintiff, or even to convey it to him, whether this property involved legal claim rights, liberties, powers, or immunities.

(c) The plaintiff might obtain from a court of equity some remedy which he could not get from a court of law, either because the common law would not allow that remedy in those circustances, or because the remedy was unknown to the court of law (as in the case of specific performance, rectification of deeds, or court administration of an estate).

It is very important to note how the court of equity went about applying and enforcing its remedies. It had no power over other courts, of course; and so never interfered in any way with the operations of the other courts' judges or officers. Rather, it acted on the individual parties before

3 Hohfeld, Some Fundamental Legal Conceptions as Applied in Judicial Reasoning (1913), 23 Yale L.J. 16, (1917), 26 Yale L.J. 710, both reprinted in Hohfeld, Fundamental Legai Conceptions (1923) as Chapters I and II. 
the courts. We tend to think of equity as a repository of a wide variety of remedies, but in a very important sense its remedies were narrower in scope than those of the courts of law. Equity could produce many results, but it produced all of them through one basic method, compulsion of the defendant. Of course, the common law courts often worked this way, for they would imprison a debtor who failed to pay a debt. But the courts of law had many other methods which could be more direct. For example, where title to property was in dispute, a court of law would simply make the successful party the owner. Equity could not do that. ${ }^{3 a}$ Chancery's first and foremost method was compulsion by injunction, on pain of attachment and imprisonment for contempt of court for failure to perform. For instance, if equity wished to affect the title to a piece of land, the unsuccessful party in equity would be ordered to convey it at law to the successful party. If he did not, he was imprisoned; equity acted in personam." If he remained obdurate and refused to convey, Chancery still would not directly affect the title to the land. It might order sequestration," whereby an official of the court would take possession of the land and the owner's chattel and apply the chattels and profits of the land toward his equitable obligations; but in doing so it would not change the legal title to the land. Indeed, even the most drastic remedy evolved by equity did not affect the legal title. That remedy was the writ of attachment," by which the successful plaintiff in equity might be put in possession of the disputed land, and the defendant in equity enjoined not to sue for trespass in the courts of law. Of course, at common law that would make the possessor the owner against all but the true legal owner, who was being coerced into not enforcing his legal rights and remedies. Yet even then the legal owner remained in possession of his legal rights and remedies; and could, if he were hardy and obdurate enough, exercise them.

Thus, although at law one might have claim rights, powers, liberties, or immunities, the Court of Chancery said nothing as to what the courts of law should do to recognize them; nor did it take away those claim rights, powers, liabilities, or immunities. Chancery only imposed a new equitable duty not to exercise them, on the ground that their exercise would be unconscionable. What did this mean? What was the final outcome of the two parties' suit in Chancery? Was the final result different from what it would have been had Chancery not been there to intervene? Obviously it was, for to obtain a different result was the very reason plaintiffs went to equity. Certainly, Lord Eldon did not attract litigants because of the rapidity and economy of the procedure ${ }^{i}$ he offered; they came to Chancery because it gave them a result no other court would give.

The rules of law were treated as complete and governing every possible situation. By reason of that, in every suit brought before a court of law, over a given fact situation, there had to be a finding in favour of either one party or the other. Yet, had each given fact situation been brought before the Court of Chancery, equity might have decided in favour of the party opposite to the one favoured by the law. Thus, whenever

Ja Until (Imp.) 11 Geo. 4 \& I Wm. 4, c. 36, s. 15, r. 15 (1830).

4 Maitland, Equity 9, 322.

i Cook, Powers of Courts of Equity (1915), 15 Col. L. Rev. 37, 110-13.

a Id. at 123-25.

i Holdsworth, ante, n. 2, at 437-45 and v. 9, pp. 342-71 (1926). 
equity would produce a different result, the rule of equity, at least so far as results were concerned, conflicted with the legal rule. Furthermore, in that sense the majority of equitable rules were inconsistent with their legal counterparts, for almost all equitable rules were born for the very reason that they produced a result unobtainable, on the given facts, at law. Therefore, Hohfeld ${ }^{8}$ in one sense is quite right in saying law and equity conflicted; indeed, he is too timid-in the above view of things equity almost always conflicted with law, so far as equity had anything to say at all on a subject. Hohfeld is wrong to confine the conflicts to a few odd cases, such as impeachment for waste.

Let us consider the classic case of the man to whom another conveyed land on trust. At law, the recipient became the owner of the fee simple, which meant that he had a liberty to keep others off the land; while everyone else, including the donor, had a duty to stay off it and not to interfere with his enjoyment of it. The recipient had a legal liberty to do what he wished with the land; and neither the donor nor anyone else had a claim right to the contrary, or even a liberty or power to stop him. Thus, the recipient had the liberty of letting the land remain idle, of letting it be overrun by weeds, and of extracting all the value from the land by the most careless and malicious methods possible, even burning down the buildings. The recipient at law even had the power and the liberty to convey title to anyone in the world, and no one else could impair this power or take the property from him. Yet, however limited the tools of Chancery might be, the result in equity would be substantially different, for the donor could claim as cestui que trust and could radically alter the recipient's relations with him, even if not with third parties. Unless the owner were willing to disobey Chancery's orders and languish in prison, he was under an equitable duty to allow the cestui the use of the land, which effectively negated his own claim right; he was under an equitable duty to husband the land's resources, which negated his legal liberty to let it go to ruin; he was under an equitable duty to convey the land to the cestui, which negated his legal liberty to convey or not as he pleased. So far as the end result is concerned, the rules of law and equity clashed in all these respects. Chancery no longer left the legal owner free to enjoy his claim rights, or even his liberties, powers, or immunities.

Of course, there were large areas of the law, such as the criminal law, or most of torts, in which equity did not interfere. But in other areas where it did interfere, must we conclude that it clashed with the law? Must we see equity, too, as a complete code covering every situation, so that where it did not countermand law's orders, then it implicitly affirmed them?' ${ }^{0}$ That is not an illogical view, but it tends to mislead. The historical growth and operation of equity was as a remedy for certain injustices, rather than a complete body of rules; and so equity's failure to intervene was mere inaction or silence, not an affirmative finding for one party or the other. Equity might fail to intervene, not only where the re-

8 Hohfeld, The Relations Between Equity and Law (1913), 11 Mich. L. Rev. 537, reprinted in Hohfeld, ante, n. 3, especially at pp. 115-22, 152-53. See also Cook, Powers of Courts of Equity (1915), 15 Col. L. Rev. 37, 106, 228; Cook, Equitable Defences (1923), 32 Yale L.J. 645. There is a very good review of the authorities on the conflict of law and equity at pp. 646-49 of this last article.

o Hohfeld, ante, n. 8. 
sult in law seemed just, but also where the party unsuccessful at law was debarred from seeking equitable relief. His own unfair conduct or long delay might be such that equity would let the situation at law stand, however imperfect it might be. To see equity as a complete concurrent system always affirming or denying law's verdict may not be strictly illogical; but it is a view which distorts the reasoning of the equity judges, and obscures the history and methods of Chancery.

Much the same thing seems to be true of the supposed conflict between legal and equitable rules. Equity usually did produce a result different from that which law ordained, and Hohfeld saw this as sufficient basis for a complete clash between the systems. He said ${ }^{10}$ that if the legislature today created a new court which could prevent the enforcement of existing rights, duties, liberties, and so forth, we would never doubt that this legislation changed the law.

Is this the right approach? May there not be more to the question than just looking at the results in individual cases? Professor Hart states that one cannot simply define the rules of the legal system in terms of what results are produced in each fact situation, for three reasons. In the first place, rights, duties, and other legal concepts are but intermediate stages in a long, complicated process of reasoning and activity; and so their place and function cannot be properly described without describing the whole system and how it works. Any attempt to do less only gives a distorted and oversimplified, two-dimensional picture of the legal concept being described. ${ }^{11}$ The second difficulty is similar to the first, and stems from the fact that many rules of a legal system are best seen, not in terms of the limits of a narrow rule, but as a wide rule which is subject to exceptions. ${ }^{12}$ For example, one cannot really define murder at common law without providing a list of exceptions for lawful excuse, compulsion, mistake of fact, accident, automatism, insanity, and so forth. Any attempt to provide a description of what murder is which takes account of all these at the outset, and so needs no exception, will fail. To make the attempt assumes that there is a common element in all situations which are murder, the lack of which is reflected in the exceptions; but this may not be so. Therefore, any attempt to give a simple, narrow, precise, twodimensional definition of murder may fail-all the more because it ignores that fact that there are several stages of reasoning, not just one stage, involved in deciding whether a man is guilty of murder. If this same reasoning applies to the relation between law and equity, so that rules of equity correspond to exceptions, and legal rules correspond to the general rule out of which the exceptions are carved, then law and equity are separate. In other words, there is not a single resultant code giving a result for each fact situation; but, rather, two independent sets of rules, each with its peculiar logic and methods, the two sometimes overlapping, and sometimes not. This view is reinforced by the long history of law and equity as separate institutions administered separately according to different principles and ways of thinking, the one strict and formal,

10 Hohfeld, Supplemental Note on the Conflict of Law and Equity (1917), 26 Yale L.J. 767, reprinted in Hohfeld, ante, n. 3, at 155-59.

11 Hart. Definition and Theory of Jurisprudence 5ff. (1953), reprinted in (1954), 70 L.Q.R. 37

12 Hart, The Ascription of Responsibility and Rights [1948-49] Proc. Arist. Socy., reprinted in Essays in Language and Logic (1st series) (ed. Flew) at 145. 
the other much concerned with good conscience. Yet another argument for this view is provided by Hart's third objection to the view which would look only at results. He says ${ }^{13}$ that any statement of a rule implies the operation of a legal system as its context. If that is true, then, at least up to the 1850's, legal and equitable rules implied different contexts, for they were administered by different courts; they could not logically conflict, for they were not on the same plane, and did not govern the actions of the same judges and court officials.

Therefore, we cannot be content with the notion that law and equity produced conflicting results in particular cases. Where one party had a claim which would succeed at law, but the other party prevented him from proceeding on the basis of a common injunction issued out of Chancery, the legal claim was inoperative and unenforceable to that extent. ${ }^{14}$ But logically it was not destroyed, for the countervailing equitable claim operated in a different context.

This is not airy theorizing or a mere distinction without a difference, for the legal rule still could have many practical consequences. It would be of full force and effect if the person with the equitable claim lacked the clean hands necessary to get relief from a court of equity, or if any other equitable defence applied. Nor would the court of equity act where the defendant's conscience was clear, for the legal right could at any time pass into the hands of a bona fide purchaser for value without notice, and spring back to its full vigor.

Consider the example of a trust. If the function of Chancery was simply to do what was necessary to produce justice and otherwise to interfere as little as possible and leave untouched as many of the legal rules as possible, the legal rights, duties, liberties, and so forth of the parties might be little changed. Thus, if $A$ held on trust for $B$ for life, remainder to $C$ and his heirs, then the only duties which equity would impose upon $\mathrm{A}$ would be those of keeping the property intact and incomebearing, and paying the net proceeds proportionately to those entitled. But for all other purposes $A$ would be the owner, and $B$ and $C$ and his heirs would have no rights over the property. They could not enter into possession, trespass on the property, injure it, tell $\mathrm{A}$ how to run it, alienate it, or otherwise use or enjoy anything but the share of net proceeds which the trustee had duly paid them. This situation is far better described in terms of A's ownership with a few superadded equitable duties, than in terms of the net resultant of the legal and equitable rules, which would be patternless and impossible to describe simply and without merely giving a catalogue of all the individual rules.

Most important of all, in the trust example, A's rights, powers, liberties, etc., vis-dे-vis third parties were not changed one iota. It was still possible for him to give good title to a bona fide purchaser for value without notice; and, even if his purchaser did not come within this class, still the conveyance to him would be valid-the purchaser would simply owe some additional duties to the cestuis que trust. There is a parallel in the corporation, for we do not say that the shareholders "really" own the company's assets, or speak of a conflict between the

13 Hart, Definition and Theory of Jurisprudence 9, 16.

14 Salmond, Jurisprudence 280-82 (s. 81) (11th ed. 1957). 
directors' legal powers with respect to the property and their duties to the shareholder. ${ }^{15}$

To sum up, then, it is equally logical to say either that law and equity conflicted or did not conflict, before the passing of modern legislation on equity. Which view one chooses to accept depends upon which facet of the situation one wishes to emphasize-the new duties inter partes or the old remaining rights, liberties, powers and immunities inter partes; the situation between the defendant in equity and his plaintiff in equity or between the defendant and the rest of the world.

\section{The Nineteenth Century Statutes}

Many of the delays in Chancery litigation in the Nineteenth Century were caused by the fact that neither the legal nor the equitable courts had all the powers necessary to dispose of most cases. This resulted in endless shuttling back and forth between courts. Procedural reform was urgent; and, therefore, Lord Cairns' Act $^{10}$ was passed to give Chancery the power to award damages as well as, or along with, its equitable remedies, while, conversely, the Common Law Procedure Act, $1854^{17}$ gave the common law courts some power to award equitable remedies and to recognize equitable defences. This did a great deal to remove the need for interrupting litigation in one court while an incidental question was settled in another court. Finally, the logical step was taken of abolishing the duplication of courts by replacing the courts of law and equity with one new court, the Supreme Court of Judicature, which was given all the powers of all the old courts. The new Supreme Court was to have different divisions for administrative convenience and specialization of work; but all the divisions were parts of the same court, and as such had identical powers. ${ }^{18}$

In addition to these procedural changes, there were changes in the substantive law as well. The Judicature Act ${ }^{19}$ made nine specific changes in the law, mostly to replace certain legal rules with the corresponding equitable rules, as, for instance, in the cases of assignment of choses in action and liability for waste. Then, a final subsection provided that, in any other case of conflict or variance between the rules of law and equity, the equitable rule was to prevail. As has been repeatedly pointed out, ${ }^{20}$ the courts have rarely given much effect to this last provision. But in the light of the conclusions we have reached, above, as to the state of law and equity before the Judicature Acts, this was not a blind refusal by the courts to accept the logic of the situation. Still less was it because the preceding specific provisions of section 25 of the 1873 Judicature Act had exhausted all the actual conflicts or variances between law and equity. Rather, the courts had the choice of two equally logical views-one that equity almost always conflicted with law because it produced different results, and the other that the two systems never conflicted because they were independent, operating on different planes.

15 Cf. Hohfeld, The Nature of Stockholders' Individual Liability for Corporation Debts (1909), 9 Col. L. Rev. 285, 290-91; Hart, Definition and Theory in Jurisprudence 6, 17-28. 10 Chancery Amendment Act (Imp.) 21 \& 22 Vict., c. 27, s. 2.

17 (Imp.) 17 \& 18 Vict., c. 125 , ss. $79,83,85$.

18 Supreme Court of Judicature Act, (Imp.) 36 \& 37 Vict., c. 66; Supreme Court of Judicature Act, (Imp.) 38 \& 39 Vict., c. 77.

10 (Imp.) 36 \& Vict., c. 66, s. 25; now see Judicature Act, R.S.A. 1955, c. 164, s. 34.

20 See Steer, ante, n. 1; Maitland, Equity $16 \mathrm{ff}$. 
The courts rejected the former view, probably with the history of equity's growth in mind, yet thereby attaining the result which was more in keeping with the spirit and reasoning of equity.

The justification for this result may seem excessively speculative and metaphysical, but the results are anything but impractical. Today one can still use an equitable defence, or obtain an equitable remedy, only on facts which would have supported such a defence or remedy before $1875 .{ }^{21}$ One cannot obtain specific performance, or damages in lieu of specific performance, in the same circumstances as those in which one can obtain damages for breach of contract. The laches and the clean hands rules have no application where the remedy or defence in question is a legal one. An interest in property passes on the formation of a contract of sale only where equity would have granted specific performance. Above all, the greatest of all equitable institutions, the trust, still survives; and the trustee is still the owner of the trust property. Equity still rules us, but not from its grave; equity is as healthy and vital as ever. 